\title{
ANALISIS HARGA POKOK JASA LAYANAN PERIKLANAN MELALUI MEDIA SOSIAL TWITTER
}

\author{
Muhammad Reza Ramdani ${ }^{1}$, Muhammad Ashoer ${ }^{2 *}$ \\ ${ }^{1,2}$ Universitas Muslim Indonesia \\ *e-mail: reza.ramdani@umi.ac.id
}

DiPublikasi: 01/07/2021

https://doi.org/10.22225/kr.13.1.2021.40-49

\begin{abstract}
Technology is becoming a lifestyle of society in the present era, internet lanes become one of the optional paths for people who are less able to compete in normal business traffic lanes. The purpose of the research to analyze the underlying price of advertising services perspectives cost classification in a business run by one on twitter social media. This research approach is done by quantitative descriptive, The type of data used in the form of cost reports on makassar promo twitter account. Data analysis is done by selling price determination method, to find out how much is appropriate for each ad. The results showed that there has not been a classification of costs carried out by makassar promo accounts, so there is a burden that is not taken into account in the study of the basic price of services.
\end{abstract}

Keywords: Media Social, Basic Price, Price.

\begin{abstract}
Abstrak
Teknologi menjadi pola hidup masyarakat di era sekarang, jalur internet menjadi salah satu jalur opsional bagi masyarakat yang kurang mampu bersaing dalam jalur lalu lintas bisnis normal. Tujuan penelitian untuk menganalisis harga pokok jasa periklanan perspektif klasifikasi biaya dalam bisnis yang dijalankan oleh salah satu pada media sosial twitter. Pendekatan penelitian ini dilakukan dengan deskriptif kuantitatif, Jenis data yang digunakan berupa laporan biaya pada akun twitter makassar promo. Analisis data dilakukan dengan metode penentuan harga jual, untuk mengetahui berapa harga yang sesuai untuk setiap iklannya. Hasil penelitian menunjukkan bahwa belum adanya pengklasifikasian biaya yang dilakukan oleh akun makassar promo, sehingga terdapat beban yang tidak diperhitungkan dalam penentuan harga pokok jasa.
\end{abstract}

Kata Kunci : Media Sosial, harga pokok, harga.

\section{PENDAHULUAN}

Perkembangan era digital dunia telah ikut mempengaruhi perkembangan perekonomian di Indonesia. Kemajuan teknologi ternyata memberikan dampak yang luar biasa terhadap pola hidup Sebagian besar manusia, kebanyakan mulai tergantung terhadap keinstanan yang ditawarkan oleh teknologi. Terknologi dan informasi yang semkain maju mendorong terjadinya perubahan komunikasi konvensional menjadi suatu komunikasi modern yang disebut dengan gaya hidup digital (Siswanto, 2018). Hampir semua individu telah beralih dan ikut-ikutan dalam menggunakan media sosial guna untuk memperluas serta, untuk tetap up to date dalam hal komunikasi (Crumpton, 2014). Dalam penggunaan media sosial dilakukan baik dari segi mengunggah, edit, pemasaran. Pemasaran media sosial memberikan

berbagai macam manfaat bagi organisasi/entitas pada kurun waktu pendek ataupun panjang, baik secara kuantitatif ataupun kualitatif (Ray, Riley, \& Wise, 2010). Sebagian besar akun media sosial mengandalkan pembayaran dan pendapatan dari iklan (Hsieh, Hsieh, \& Feng, 2011). Pelaku usaha sudah memanfaatkan media sosial sebagai media promosi. Media sosial yang digunakan adalah blog development $14 \%$, facebook $46 \%$, dan twitter sebanyak 39\%, alasan mereka menggunakan media tersebut karena biaya minim, mudah dikenali dan distribusi produk yang bersifat global (Dedi Rianto Rahadi, 2013). Melihat banyaknya pengguna twitter di indonesia. Hal ini tentu akan menjadi lahan bisnis untuk melebarkan usaha melalui media sosial tersebut baik dari segi promosi, serta peningkatan hubungan dengan pelanggan dan 
meningkatkan jumlah pelanggan baru (Jones, Borgman, \& Ulusoy, 2015). Salah satu akun yang melakukan kegiatan bsisnis melalui media online adalah makassar promo. Akun ini memberikan informasi mengenai barang dan jasa yang siap dipasarkan melalui akun twitter tersebut. Dengan jumlah follower atau pengikut tersebut yang mencapai angka diatas 6000 akun, hal ini menjadikan akun ini sebagai sarana alternatif untuk melakukan promosi sebuah barang dan jasa dengan biaya yang lebih terjangkau. Pemasaran dalam media sosial menjadi luas sehingga membuat

\section{TINJAUAN PUSTAKA}

(Horngren et al., 2010) menyatakan bahwa akuntansi biaya adalah proses pelacakan, pencatatan dan Analisa terhadap biaya-biaya yang dikeluarkan oleh sebuah perusahaan atau badan dalam memproduksi suatu barang atau jasa. Biaya sebagai sumber daya yang dikorbankan atau di distribusikan untuk mencapai tujuan tertentu (Hansen \& Mowen, 2018). Kaitan antara biaya dan objek biaya harus dieksplorasi sehingga dapat membantu dalam meningkatkan keakuratan penilaian serta pembebanan biaya. Biaya terdapat hubungan dengan objek biaya baik secara langsung maupun tidak langsung. Penelusuran biaya dapat

\section{METODE}

Artikel ini melakukan penelitian pada sebuah akun twitter yang menyediakan layanan jasa periklanan melalui media jejaring sosial. Pengumpulan data digunakan dengan tehnik observasi atau pengamatan langsung dalam proses aktivitas periklanan yang dilakukan oleh akun makassar promo dan dokumentasi informasi sehubungan dengan biaya yang dikeluarkan selama proses periklanan dilakukan. Metode analisis yang digunakan bersifat deskriptif dengan metode penentuan harga jual dari (Horngren et al., 2010). Untuk mengetahui berapa harga yang sesuai untuk mereka dalam tuntutannya membenarkan biaya menggunakan metrik periklanan konvensional (Fisher, 2009). Namun dalam penentuan harga pelayanan jasa dalam media sosial sering mengalami perubahan, hal ini disebabkan belum jelasnya kalsifikasi biaya dalam pelayanan jasa. Artikel ini akan melakukan kalkulasi serta mengklasifikasikan biaya yang terjadi pada jasa promosi pada akun makassar promo. Artikel ini akan berdampak pada rana teoritis dan praktis.

dilakukan dengan penelusuran langsung dan penelusuran penggerak (Niazi, Dai, Balabani, \& Seneviratne, 2006). Pencarian langsung adalah proses yang mengindentifikasi dan membebankan biaya yang secara khusus terkait dengan objek, sementara pelacakan drive menggunakan drive untuk mengisi daya objek (Charter \& Milton F, 2006). (Kotler, 2012) menyatakan bahwa jasa suatu bentuk tindakan atau majelis kerja yang diberikan oleh satu pihak kepada pihak lain, pada prinsipnya tidak berwujud dan mengarah kepada transfer kepemilikan apa pun.

setiap iklan yang diberikan melalui media sosial, dapat dihitung menggunakan rumus :

\section{"Harga Jual = Total Biaya/Beban + Margin (laba) yang diinginkan”.}

Sedangkan untuk menghitung beban langsung :

"Total beban = Beban Langsung + Beban tidak Langsung + Biaya Overhead Tidak Langsung”. 


\section{HASIL DAN PEMBAHASAN}

Tabel 1.

Data Keuangan Makassar Promo per 31 Oktober 2018

\begin{tabular}{|c|c|c|c|c|c|c|}
\hline \multirow{2}{*}{$\begin{array}{c}\text { Bulan } \\
\text { MARET } 2012\end{array}$} & \multicolumn{2}{|c|}{ Omzet/Penjualan } & \multicolumn{2}{|c|}{$\begin{array}{c}\text { Out / } \\
\text { Pengeluaran }\end{array}$} & \multicolumn{2}{|r|}{ Profit } \\
\hline & $\mathrm{Rp}$ & 150,000 & $\mathrm{Rp}$ & 190,000 & $\mathrm{Rp}$ & $-40,000$ \\
\hline APRIL 2012 & $\mathrm{Rp}$ & 850,000 & $\mathrm{Rp}$ & 175,000 & $\mathrm{Rp}$ & 675,000 \\
\hline MEI 2012 & $\mathrm{Rp}$ & 625,000 & $\mathrm{Rp}$ & 590,000 & $\mathrm{Rp}$ & 35,000 \\
\hline JUNI 2012 & $\mathrm{Rp}$ & $1,015,000$ & $\mathrm{Rp}$ & 977,000 & $\mathrm{Rp}$ & 38,000 \\
\hline JULI 2012 & $\mathrm{Rp}$ & $1,410,000$ & $\mathrm{Rp}$ & $1,245,000$ & $\mathrm{Rp}$ & 165,000 \\
\hline AGU 2012 & $\mathrm{Rp}$ & 750,000 & $\mathrm{Rp}$ & 613,000 & $\mathrm{Rp}$ & 137,000 \\
\hline SEP 2012 & $\mathrm{Rp}$ & $1,920,000$ & $\mathrm{Rp}$ & $2,425,000$ & $\mathrm{Rp}$ & $-505,000$ \\
\hline OKT 2012 & $\mathrm{Rp}$ & $3,025,000$ & $\mathrm{Rp}$ & $2,010,000$ & $\mathrm{Rp}$ & $1,015,000$ \\
\hline TOTAL & $\mathrm{Rp}$ & $9,745,000$ & & $8,225,000$ & $\mathrm{Rp}$ & $1,520,000$ \\
\hline
\end{tabular}

Sumber : Makassar Promo

Data penjualan Makassar Promo dalam kurun waktu 8 bulan, terhitung dari maret 2018 sampai dengan oktober 2018 adalah sebesar Rp. 9.745.000. Sedangkan pengeluaran setelah diakumulasikan adalah sebesar Rp. 8.225.000. Berdasarkan data tersebut, pendapatan dikurangi dengan pengeluaran, Makassar Promo mendapat keuntungan sebesar Rp. 1.520.000. Perhitungan harga pokok jasa berbeda dengan menghitung harga pokok produksi pada perusahaan manufaktur. Untuk menghitung harga pokok produksi pada perusahaan manufaktur menggunakan komponen bahan baku langsung, tenaga kerja langsung, dan biaya overhead. Sedangkan dalam perusahaan jasa dilakukan dengan cara mengkalsifikasi biaya - biaya yang dialokasikan, yaitu biaya langsung dan biaya tidak langsung.

Tabel 2.

Biaya Langsung Perusahaan Makassar Promo per Maret - Oktober 2018

\begin{tabular}{cccr}
\hline No & Keterangan & \multicolumn{2}{c}{ Nominal } \\
\hline 1 & Pembelian Domain & $\mathrm{Rp}$ & 80,000 \\
2 & Pembelian Hosting & $\mathrm{Rp}$ & 110,000 \\
3 & Gaji Admin & $\mathrm{Rp}$ & $5,500,000$ \\
\multicolumn{2}{c}{ Total } & Rp & $\mathbf{5 , 6 9 0 , 0 0 0}$ \\
\hline
\end{tabular}

Sumber : Makassar Promo

Pembelian domain atau situs resmi yang dilakukan oleh Makassar promo untuk kegiatan perusahaannya sebesar Rp. 80.000. Sedangkan hosting untuk menampung semua post yang berisi data artikel dan sebagainya dibeli seharga $\mathrm{Rp}$. 110.000. Biaya gaji untuk admin yang telah dibayarkan sebesar Rp. 5.500.000. Jadi, total untuk semua biaya tersebut adalah sebesar Rp. 5.690 .000 . 
Tabel 3.

Biaya Tidak Langsung Perusahaan Makassar Promo per Maret - Oktober 2018

\begin{tabular}{cllr}
\hline No & \multicolumn{1}{c}{ Keterangan } & \multicolumn{2}{c}{ Nominal } \\
\hline 1 & Biaya Pulsa Untuk Hadiah & $\mathrm{Rp}$ & 417,000 \\
2 & Biaya Afiliasi & $\mathrm{Rp}$ & 100,000 \\
3 & Biaya faktur (invoice) & $\mathrm{Rp}$ & 10,000 \\
4 & Beban Gremlin & $\mathrm{Rp}$ & 70,000 \\
5 & Panjar Gaji & $\mathrm{Rp}$ & 100,000 \\
6 & Beban Lain-lain & $\mathrm{Rp}$ & $1,838,000$ \\
& Total & $\mathbf{R p}$ & $\mathbf{2 , 5 3 5 , 0 0 0}$ \\
\hline
\end{tabular}

Sumber : Makassar Promo

Pembelian pulsa untuk pemberian hadiah agar menambah jumlah followers sebesar $\mathrm{Rp}$ 417,000. Biaya afiliasi untuk membangun jaringan dengan beberapa akun-akun twitter yang lain sebesar Rp. 100.000. Biaya faktur (invoice) senilai Rp 10,000. Pembayaran aplikasi gremlin untuk aplikasi pengirim tweet otomatis sebesar Rp. 70.000. panjar gaji admin sebesar Rp. 100.000. Serta beban lain-lain yang dikeluarkan sebesar Rp. 1.838.000. Jadi, total biaya tidak langsung yang dialokasikan sebesar $\mathrm{Rp}$. 2.535.000.

Tabel 4.

Perhitungan Harga Pokok Jasa Makassar Promo Periode Maret Sampai Oktober 2018

Penjualan/Omzet

$\operatorname{Rp} 9,745,000$

Dikurangi Beban :

Harga Pokok Penjualan Jasa

Beban Langsung

Total Beban Langsung

$$
\begin{aligned}
& \text { Pembelian Domain } \\
& \text { Pembelian Hosting } \\
& \text { Gaji Admin }
\end{aligned}
$$

Laba Kotor

Dikurangi Biaya Tidak Langsung :

Biaya Pulsa Untuk Hadiah
Biaya Afiliasi
Biaya Invoice
Beban Gremlin
Panjar Gaji
Beban Lain-lain

Total Biaya Tidak Langsung

Margin Bersih

Sumber : data diolah

Perhitungan diatas menjelaskan seberapa besar laba yang diperoleh perusahaan dalam menjalankan bisnisnya. Berdasarkan perhitungan diatas diketahui laba perusahaan adalah sebesar

$$
\begin{array}{lr}
\text { Rp } & 80,000 \\
\text { Rp } & 110,000 \\
\text { Rp } & 5,500,000
\end{array}
$$

$\frac{(\operatorname{Rp} 5,690,000)}{\operatorname{Rp} 4,055,000}$

Rp $\quad 417,000$

Rp $\quad 100,000$

Rp $\quad 10,000$

Rp $\quad 70,000$

$\mathrm{Rp} \quad 100,000$

Rp 1,838,000

$(\operatorname{Rp} 2,535,000)$

Rp 1,520,000 


Beban per Kategori $=\quad \frac{\text { Jumlah Tayang }}{\sum \text { jumlah tayang }} \quad$ X Total Beban

Tabel 5.

Beban per Kategori Iklan

\begin{tabular}{lccc}
\hline \multicolumn{1}{c}{ Kategori } & $\begin{array}{c}\text { Jumlah } \\
\text { Penayangan }\end{array}$ & Beban & $\begin{array}{c}\text { Beban Per } \\
\text { Kategori }\end{array}$ \\
\hline Lite & 42 & & Rp. 799.700 \\
Silver & 90 & & Rp. 1.713 .500 \\
Gold & 150 & Rp. 8.225 .000 & Rp. 2.855 .900 \\
Platinum & 150 & & Rp. 2.855 .900 \\
\multicolumn{1}{c}{ Total } & 432 & & Rp. 8.225 .000 \\
\hline
\end{tabular}

Sumber : data diolah

Untuk kategori lite dengan jumlah penayangan sebanyak 42 kali menggunakan beban sebesar Rp. 799.700, sedangkan kategori silver untuk jumlah penayangan sebanyak 90 kali menggunakan beban sebesar Rp. 1.713.500.
Kategori gold menggunakan beban sebesar Rp. 2.855.900 untuk jumlah penayangan sebanyak 150 kali, sedangkan kategori platinum dengan jumlah penayangan sebanyak 150 kali menggunakan beban sebesar Rp. 2.855.900.

Tabel 6. Beban per Unit Iklan

\begin{tabular}{lcccc}
\hline \multicolumn{1}{c}{ Kategori } & Beban per Kategori & $\begin{array}{c}\text { Unit Terjual } \\
\text { (1) }\end{array}$ & Beban per Unit = (1) : (2) \\
\hline Lite & Rp. 799.700 & 48 & Rp. 16.600 \\
Silver & Rp. 1.713 .500 & 19 & Rp. 90.200 \\
Gold & Rp. 2.855 .900 & 16 & Rp. 178.500 \\
Platinum & Rp. 2.855 .900 & 3 & Rp. 952.000 \\
\hline Sumber data : Makassar Promo & &
\end{tabular}

Untuk kategori lite dari 48 unit yang terjual menggunakan beban sebesar Rp. 799.700 setiap unitnya, sedangkan kategori silver untuk 48 unit yang terjual menggunakan beban sebesar

beban sebesar Rp. 2.855.900 untuk 16 unit yang terjual, sedangkan kategori platinum untuk 3 unit yang terjual menggunakan beban sebesar $\mathrm{Rp}$. 2.855.900.

Rp. 1.713.500. Kategori gold menggunakan

\section{Perhitungan Harga Pokok Jasa dan Harga Jual Menurut Horngren}

a. Menghitung Penyusutan Aktiva Tetap

Perhitungan harga pokok jasa yang dilakukan oleh Makassar promo belum memasukkan besarnya biaya overhead tidak langsung dari

penyusutan aktiva tetap yang digunakan dalam menjalankan bisnisnya. Untuk menghitung besarnya biaya penyusutan digunakan rumus:
Penyusutan $=$
Harga Perolehan

Umur ekonomis 
Tabel 7.

Perhitungan Penyusutan Aktiva Tetap

\begin{tabular}{lcccc}
\hline \multicolumn{1}{c}{ Aktiva Tetap } & Harga Perolehan & $\begin{array}{c}\text { Umur } \\
\text { ekonomis } \\
\text { (bulan) }\end{array}$ & $\begin{array}{c}\text { Biaya } \\
\text { Penyusutan/Bulan }\end{array}$ \\
\hline Motor & Rp $12,000,000.00$ & 84 & Rp $142,900.00$ \\
Laptop & Rp $7,800,000.00$ & 48 & Rp $162,500.00$ \\
gadget android & Rp $2,200,000.00$ & 24 & Rp $91,700.00$ \\
gadget blackberry & Rp $1,000,000.00$ & 12 & Rp $83,300.00$ \\
\hline
\end{tabular}

Sumber : data diolah

Dari table diatas diperlihatkan seberapa besar biaya penyusutan dari setiap aktiva tetap yang digunakan dalam proses produksi. Motor untuk setiap bulannya mendapat penyusutan sebesar Rp.142.900. Laptop perbulannya sebesar Rp. 162.500, untuk android dan blackberry masing-masing sebesar Rp. 91.700 dan Rp. 83.300 disetiap bulannya.

Tabel 8.

Penyusutan Aktiva Tetap dari Maret Sampai Oktober

\begin{tabular}{lcccc}
\hline Aktiva Tetap & Penyusutan /bulan & Bulan & Penyusutan /periode \\
\hline Motor & $\mathrm{Rp} 142,900$ & 7 & $\mathrm{Rp} 1,000,300$ \\
Laptop & $\mathrm{Rp} 162,500$ & 7 & $\mathrm{Rp} 1,137,500$ \\
Gadget android & $\mathrm{Rp} 91,700$ & 1 & $\mathrm{Rp}$ & 91,700 \\
Gadget blackberry & $\mathrm{Rp} 83,300$ & 7 & $\mathrm{Rp}$ & 583,100 \\
\hline \multicolumn{2}{l}{ Sumber data : Makassar Promo } & & &
\end{tabular}

Penyusutan untuk motor dengan pemakain selama 7 bulan adalah sebesar Rp. 1.000.300, sedangkan untuk laptop sebesar Rp. 1.137.500 untuk pemakaian selama 7 bulan. Gadget android dengan pemakain 1 bulan mendapat biaya penyusutan sebesar Rp. 91.700. Sedangkan untuk gadget blackberry dengan pemakaian 7 bulan mendapat biaya penyusutan sebesar Rp. 583.100. Setelah beban penyusutan telah diketahui, maka nilai tersebut dimasukkan ke dalam perhitungan harga pokok jasa. Ini akan membuat beban bertambah dan akan mengurangi laba atau bahkan menyebabkan kerugian jika beban penyusutan sangat besar.

Tabel 9.

Perhitungan Harga Pokok Jasa Makassar Promo Periode Maret Sampai Dengan Oktober 2018 Metode Horngren

Penjualan / Omzet

Dikurangi Beban

Harga Pokok Penjualan Jasa

Beban Langsung

Pembelian Domain $\quad \mathrm{Rp} \quad 80,000$

Pembelian Hosting $\quad \mathrm{Rp} \quad 110,000$ 
Total Beban Langsung

Biaya overhead

Total Biaya

Overhead

Margin Kotor

Biaya Tidak Langsung

\section{Total Beban Tidak Langsung}

Biaya Pulsa Untuk

$\begin{array}{llr}\text { Hadiah } & \mathrm{Rp} & 417,000 \\ \text { Biaya Afiliasi } & \mathrm{Rp} & 100,000 \\ \text { Biaya Invoice } & \mathrm{Rp} & 10,000 \\ \text { Beban Gremlin } & \mathrm{Rp} & 70,000 \\ \text { Prive } & \mathrm{Rp} & 100,000 \\ \text { Beban Lain-lain } & \mathrm{Rp} & 1,838,000\end{array}$

$\begin{array}{llc}\text { Penyusutan motor } & \text { Rp } 1,000,300 \\ \text { Penyusutan laptop } & \text { Rp } 1,137,500 \\ \text { Penyusutan android } & \text { Rp } & 91,700 \\ \text { Penyusutan blackberry } & \text { Rp } & 583,100\end{array}$

$$
\text { Rp5,690,000 }
$$

$\operatorname{Rp} 2,812,600$

Rp 2,535,000

(Rp. $11,037,600)$

$\operatorname{Rp} \quad(1,292,600)$

Margin Bersih

Sumber : data diolah

Dari perhitungan di atas terdapat selisih sebesar Rp 2.812.600 yang diperoleh dari biaya overhead yang ditambahkan dalam perhitungan tersebut, setelah biaya overhead dimasukkan, ternyata bisnis yang dijalankan mendapat kerugian dalam menjalankan kegiatan bisnisnya. Kerugian tersebut sebesar Rp. 1.292.600. Hal ini juga akan berpengaruh pada margin (laba) per unit iklan dari masing-masing kategori yang ada dan margin dari tiap unit iklan yang terjual setelah biaya overhead dimasukkan.

Harga Jual Jasa Pelayanan metode Horngren

(Horngren, Harrison, \& Oliver, 2012) untuk mengitung harga jual dari setiap barang produksi dapat menggunakan rumus sebagai berikut:

\section{total beban per unit + margin yang dinginkan}

Jadi, perhitungan dapat dilakukan kemudian ditambahkan dengan margin (laba) yang diinginkan. dengan mengklasifikasikan semua beban yang dikeluarkan untuk proses produksi

Total beban $=$ ban Langsung $\quad \begin{gathered}\text { Beban Tidak } \\ \text { Langsung }\end{gathered}+\quad \begin{gathered}\text { ya Overhead Tidak } \\ \text { Langsung }\end{gathered}$

Total Beban $=$ Rp. $5.690 .000+$ Rp. $2.535 .000+$ Rp. 2.812 .600

Total Beban $=$ Rp. 11.037.600

Untuk menghitung beban per kategori digunakan rumus sebagai berikut: 
Beban per Kategori $=\quad \frac{\text { Jumlah Tayang }}{\sum \text { jumlah tayang }}$ X Laba Bersih

Table 10.

Beban Per Kategori

\begin{tabular}{cccc}
\hline Kategori & $\begin{array}{c}\text { Jumlah Iklan } \\
\text { Tayang }\end{array}$ & Total Beban & Beban per Kategori \\
\hline Lite & 42 & & Rp. 1.073 .100 \\
Silver & 90 & Rp. 11.037 .600 & Rp. 2.299 .500 \\
Gold & 150 & & Rp. 3.832 .500 \\
Platinum & 150 & & Rp. 11.037 .600 \\
Total & 432 & &
\end{tabular}

Sumber : data diolah

Beban dalam kategori lite sebesar Rp. 1.073.100 yang dibagi secara proporsional berdasarkan dengan jumlah iklan tayang sebanyak 42 kali., dengan total keseluruhan dari jumlah iklan. Beban dalam kategori silver sebesar Rp. 2.299.500 yang dibagi secara proporsional berdasarkan dengan jumlah iklan tayang sebanyak 90 kali, dengan total keseluruhan dari jumlah iklan. Kategori gold beban per kategori sebesar Rp. 3.832 .500 yang dibagi secara proporsional berdasarkan dengan jumlah iklan tayang sebanyak 150 kali, dengan total keseluruhan dari jumlah iklan. Sedangkan kategori platinum beban per kategori sebesar Rp. 3.832 .500 yang dibagi secara proporsional berdasarkan dengan jumlah iklan tayang 150 kali, dengan total keseluruhan dari jumlah iklan.

Table 11.

Beban per unit

\begin{tabular}{lccccc}
\hline \multicolumn{1}{c}{ Kategori } & beban per Kategori & $\begin{array}{c}\text { Unit yang Terjual } \\
\text { (2) }\end{array}$ & \multicolumn{2}{c}{$\begin{array}{c}\text { beban per Unit }= \\
\text { (1) : (2) }\end{array}$} \\
\hline Lite & Rp. & 1.073 .100 & 48 & Rp. & 25.400 \\
Silver & Rp. & 2.299 .500 & 19 & Rp. & 121.000 \\
Gold & Rp. & 3.832 .500 & 16 & Rp. & 239.500 \\
Platinum & Rp. & 3.832 .500 & 3 & Rp. 1.277 .500 \\
\hline Sumber : data diolah & & & & &
\end{tabular}

Beban per unit dalam kategori lite sebesar Rp. $\quad 25.400$ yang diperoleh dari beban per kategori sebesar Rp. 1.073.100 / unit yang terjual sebanyak 48 unit. Beban per unit dalam kategori silver sebesar Rp. 121.000 yang diperoleh dari beban per kategori sebesar Rp. 2.299.500 / unit yang terjual sebanyak 19 unit. Beban per unit dalam kategori gold sebesar Rp. 239.500 yang diperoleh dari beban per kategori sebesar Rp. 3.832.500 / unit yang terjual sebanyak 16 unit. Beban per unit dalam kategori platinum sebesar Rp. 1.277.500 yang diperoleh dari beban per kategori sebesar Rp. 3.832.500 / unit yang terjual sebanyak 3 unit. 
Tabel 12.

Penentuan harga jual per unit

\begin{tabular}{lrrrrrrr}
\hline \multicolumn{1}{c}{ Kategori } & \multicolumn{2}{c}{ Beban } & Margin & $\begin{array}{r}\text { Laba Yang } \\
\text { Diinginkan }\end{array}$ & Harga Jual \\
\hline Lite & Rp. & 25.400 & $50 \%$ & Rp. & 12.700 & Rp. & 38.100 \\
Premium & Rp. & 121.000 & $50 \%$ & Rp. & 60.500 & Rp. & 181.500 \\
Gold & Rp. & 239.500 & $50 \%$ & Rp. & 119.750 & Rp. & 359.250 \\
Platinum & Rp. 1.277 .500 & $10 \%$ & Rp. & 127.750 & Rp. & 1.405 .250 \\
\hline Sumber : data diolah & & & & & &
\end{tabular}

Harga jual untuk paket lite sebesar Rp. 38.100 dengan kenaikan sebesar 50\% dari harga pokok jasanya. Sedangkan harga jual untuk paket silver sebesar Rp. 181.500 dengan kenaikan sebesar $50 \%$ dari harga pokok jasanya. Paket gold memiliki harga jual sebesar Rp. 359.250 dengan margin yang diinginkan sebesar $50 \%$ dari harga pokok jasanya, sedangkan untuk paket

Table 13.

Perbandingan tarif harga Makassar promo dengan tarif yang dihitung berdasarkan Metode Horngren

\begin{tabular}{lrrrrrr}
\hline Kategori & Tarif Makassar Promo & \multicolumn{2}{c}{$\begin{array}{c}\text { Harga Jual } \\
\text { Berdasar Metode } \\
\text { Horngren }\end{array}$} & \multicolumn{2}{c}{ Selisih } \\
\hline Lite & Rp. & 65.000 & Rp. & 38.100 & Rp. & 26.900 \\
Silver & Rp. 125.000 & Rp. & 181.500 & Rp. & 56.500 \\
Gold & Rp. 200.000 & Rp. & 359.250 & Rp. & 159.250 \\
Platinum & Rp. 350.000 & Rp. 1.405 .250 & Rp. 1.055 .250 \\
\hline
\end{tabular}

Sumber : data diolah

Dari table diatas terihat perbedaan antara harga jual yang ditetapkan oleh Makassar Promo dengan harga jual yang telah dihitung berdasarkan dengan teori horngren. Diantara keduanya terdapat selisih. Untuk kategori lite terdapat selisih sebesar Rp. 26.900, dimana harga pelayanan jasa yang ditetapkan oleh Makassar Promo sebesar Rp. 65.000, sedangkan jika dihitung berdasarkan teori harga jual sebenarnya adalah Rp. Rp. 38.100. untuk kategori silver terdapat selisih sebesar Rp. 56.500, dimana harga jual yang ditetapkan oleh Makassar Promo sebesar Rp. 125.000, sedangkan jika dihitung berdasarkan teori harga jual sebenarnya adalah Rp. Rp. 181.500. untuk kategori gold terdapat selisih sebesar Rp. 159.250, dimana harga pelayanan jasa yang ditetapkan oleh Makassar Promo sebesar Rp. 200.000, sedangkan jika platinum dinaikkan sebesar $10 \%$ dari harga pokok sehingga mendapat harga jualnya sebesar Rp. 1.405.250. Setelah penetapan harga jual yang dilakukan secara teori maka terdapat perbedaan dengan penetapat harga jual yang dilakukan oleh Makassar Promo. Perbedaan tersebut dapat dilihat pada tabel 12 . 
Makassar promo tidak ada biaya overhead tidak langsung dari penyusutan aktiva tetap. Sedangkan perhitungan tarif menurut teori

\section{KESIMPULAN DAN SARAN \\ Simpulan}

Hasil penelitian tersebut menjelaskan tidak adanya penetapan anggaran seberapa besar biaya yang dikelaurkan untuk pembelian pulsa untuk kegiatan operasional Makassar promo, melainkan biaya pulsa tersebut harus dialokasikan dari gaji admin masing - masing. Dalam menjalankan usahanya, Makassar Promo, tidak menggunakan pengklasifikasian biaya sehingga tidak memperhitungkan overhead penyusutan perlengkapan yang mengakibatkan kerugian. Terdapat distorsi harga jual diantara perhitungan yang dilakukan oleh Makassar promo dengan

\section{DAFTAR PUSTAKA}

Charter, W., \& Milton F, U. (2006). Akuntansi Biaya. Salemba Empat.

Crumpton, M. A. (2014). Accounting for the cost of social media. Bottom Line. https://doi.org/10.1108/BL-062014-0017

Dedi Rianto Rahadi, L. A. A. (2013). The utilization of social networking as promotion media (Case study: Handicraft business in Palembang). SESINDO2013 Conference. Seminar Nasional Sistem Informasi Indonesia (SESINDO). Retrieved from https://arxiv.org/abs/1312.3532

Fisher, T. (2009). ROI in social media: A look at the arguments. Journal of Database Marketing and Customer Strategy Management. https://doi.org/10.1057/dbm.2009.16

Hansen, D. R., \& Mowen, M. M. (2018). Cornerstones of Cost Management. Cengage Learning.

Horngren, C. T., Foster, G., Datar, S. M., Rajan, M., Ittner, C., \& Baldwin, A. A. (2010). Cost Accounting: A Managerial Emphasis,. Issues in Accounting Education. https://doi.org/10.2308/iace.2010.25.4.789

Horngren, C. T., Harrison, W., \& Oliver, S. (2012). Financial memasukkan semua unsur - unsur biaya yang ada. Karena hal tersebut akan menambah harga pokok jasa.

metode horngren dalam menentukan harga jualnya.

\section{Saran}

Perlunya pengkalsifikasiaan biaya serta pengalokasian biaya untuk mencegah besarnya cost yang dapat melebar dan dapat menyebabkan kerugian. Penelitian hanya terbatas pada harga pokok. Rekomendasi untuk penelitian selanjuntya sebaiknya lebih melirik pendekatan motif serta alokasi biaya.

and Managerial Accounting. In Management Accounting Research.

Hsieh, Y., Hsieh, J., \& Feng, Y. (2011). Switching between social media: The role of motivation and cost. IPEDR.

Jones, N., Borgman, R., \& Ulusoy, E. (2015). Impact of social media on small businesses. Journal of Small Business and Enterprise Development. https://doi.org/10.1108/JSBED-09-2013-0133

Kotler, P. (2012). Kotler On Marketing. In Kotler On Marketing.

Niazi, A., Dai, J. S., Balabani, S., \& Seneviratne, L. (2006). Product cost estimation: Technique classification and methodology review. Journal of Manufacturing Science and Engineering, Transactions of the ASME. https://doi.org/10.1115/1.2137750

Ray, A., Riley, E., \& Wise, J. (2010). The ROI Of Social Media Marketing. Interactive Marketing.

Siswanto, T. (2018). Optimalisasi Sosial Media Sebagai Media Pemasaran Usaha Kecil Menengah. Liquidity. https://doi.org/10.32546/lq.v2i1.134 